European journal of American studies

Spring 2006

\title{
American Studies in Italy
}

Part 2 : U.S. History in Italy at the beginning of the 21st Century

\section{OpenEdition}

\section{Journals}

Electronic version

URL: https://journals.openedition.org/ejas/404

DOI: $10.4000 /$ ejas.404

ISSN: 1991-9336

Publisher

European Association for American Studies

Electronic reference

Ferdinando Fasce, "American Studies in Italy", European journal of American studies [Online], 1-1 | 2006, document 11, Online since 13 January 2006, connection on 09 July 2021. URL: http:// journals.openedition.org/ejas/404 ; DOl: https://doi.org/10.4000/ejas.404

This text was automatically generated on 9 July 2021.

Creative Commons License 


\section{American Studies in Italy}

Part 2 : U.S. History in Italy at the beginning of the 21st Century

In the early 1990s, introducing the Journal of American History's internationalization project, Maurizio Vaudagna urged his Italian colleagues ${ }^{1}$ and all "non-English-speaking American historians in Europe [...] to abandon the melancholic but somewhat comfortable situation of being marginal in both worlds." ${ }^{2}$ More than a decade later, now that studying American history has been enormously complicated by the seismic changes connected with the end of the Cold War, the tragedy of $9 / 11$, and the attendant reshaping of Atlantic relations ${ }^{3}$, the questions posed by Vaudagna's remarks still defy unambiguous answers. Yet it seems safe to say that some limited, but unmistakable results in terms of research and scientific work have been achieved along lines of interaction and exchange ${ }^{4}$ probably not so remote from those Vaudagna wished to see. For all the difficulties encountered by the humanities ${ }^{5}$ in Italy and elsewhere in this current recession, the very small group of Italian historians of the U.S.-in all 26 people with official tenured appointments ${ }^{6}$ plus another dozen scholars dealing in various ways with U.S. history but not officially classified as such, some of them still waiting for their chance to break into the academic system-have taken advantage of the opportunities for conversation and joint projects available both at a European and American level. ${ }^{7}$

2 This line of development clearly emerges if we look at the practitioners still raising the flag for the now long waning sub-fields of colonial, Revolutionary and Civil War studies. old Guard scholars such as Raimondo Luraghi and Tiziano Bonazzi, Americanists of the so-called "third generation" who came of age in the 1970s such as Luca Codignola, Susanna Delfino, and Ellen Migliorino Ginzburg, and their younger colleague Marco Sioli-all participate actively in international research networks and educational programs connected with their specific areas of inquiry. ${ }^{8}$ The pursuit of a transnational and comparative approach is even more evident if we glance at the three main lines of research that, with remarkable continuity, have emerged as predominant in the past fifteen years. Such is the case with migration studies, which make up one third of the monographs published during this period, a development reflecting the interplay between a current domestic concern (the emerging condition of Italy as an immigrant country) and an over-long-neglected story of Italian emigration and the "Italian 
workers of the world," to quote the title of the most important research joint-venture of scholars of Italian descent on both sides of the Atlantic. ${ }^{9}$ Increasingly shrinking financial resources at our universities may have also played a part in prompting students to turn to migration studies, given the recent availability of more easily affordable sources in such national repositories located in Rome as the National Archives, the State Department and the Vatican Archives $^{10}$, as well as in local repositories. Matteo Sanfilippo has provided an exhaustive review of the substantial body of work covering the most diverse areas of the migratory experience. Carried out largely under the tutorship of Anna Maria Martellone, this work includes the enquiries conducted by Bruno Cartosio, Elisabetta Vezzosi, Susanna Garroni, and Ferdinando Fasce on immigrant labor, Maddalena Tirabassi's study of Italian women and the complex process of "Americanization" they engaged in at the turn of the century, Nadia Venturini on the relations between Italians and Afroamericans in the interwar years, Matteo Sanfilippo on religiosity, Stefano Luconi on Italians in U.S. politics, and Simone Cinotto on Italian-American cuisine as a vehicle for negotiating a hybrid cultural identity within American society. ${ }^{11}$

Some of the aforementioned archives have also been instrumental in shaping the studies of international relations, which make up one quarter of the monographs published since the early 1990s. Inspired by the dramatic reconfiguration of the Italian and European role in the age of globalization and international terrorism, such studies have been nurtured by constant exchanges at several institutions including the European University Institute, the London School of Economics, the Cold War History Project at NYU, and the Charles Warren Center at Harvard. Placing Italian-U.S. relations against a larger European and transnational background, they range in scope from Wilsonianism to cultural diplomacy in the interwar age, from the Marshall Plan to the question of Americanization. They include Federico Romero's pioneering research on the role played by the unions on both sides of the Atlantic in bringing about European Reconstruction, his student Mario Del Pero's insightful scrutiny of the relations between the U.S. and the Christian Democrats, Italy's leading party and the main partner of the U.S. administrations in the post-World War II era, Daniela Rossini's analysis of the "Wilsonian myth" in Italy in the aftermath of World War I, and Antonio Donno's work on American Cold War policy in the Middle East. ${ }^{12}$ Besides filling important gaps in historical knowledge, these studies have also contributed to reinvigorating the larger field of the history of international relations, a discipline that lately in Italy has witnessed a sharp drop in the number of publications. ${ }^{13}$

International contacts and collaboration also underlie the third stream of research, which might be called "new dimensions of political history," ${ }^{14}$ in the broadest possible sense, in the twentieth century. Comprising one third of the most recent monographs and reflecting current widespread concerns about democracy at a time of deep economic and cultural disruption, this composite cluster of enquiries has branched out into the study of political and public culture (Raffaella Baritono, Oliviero Bergamini, Daniele Fiorentino, Daria Frezza, Marco Mariano, and Arnaldo Testi), race and gender issues (Alessandra Lorini, Vezzosi, and Baritono), and mass society and the politics of consumption (Cartosio, Fasce, Cristina Scatamacchia). ${ }^{15}$ In the process its practitioners have addressed the interplay between "Private and Public", to borrow the formula from the most important recent national collective enterprise of research, which has brought together Italian historians and literati of the U.S. ${ }^{16}$ 
The brainchild of Vaudagna, this project is the culmination of a series of research and educational initiatives, open to European and international collaboration, as well as in close cooperation with Italian modern and contemporary historians ${ }^{17}$, that Vaudagna has been developing since the early 1990s around the Bairati Centre in Turin. Drawing on both private and public financial resources, the Bairati Centre has knitted together research, public initiatives aimed at a wider audience than the academic one, and educational activities. In its wake other centres have sprung up, such as the Centro di Ricerca in Studi Canadesi e Colombiani and the Centro Studi Euro-Atlantici (CSEA) ${ }^{18}$, founded and directed by Luca Codignola (with Massimo Rubboli) and Valeria Gennaro Lerda, respectively, both at the University of Genoa. They have recently been joined by the Centro interuniversitario di storia e politica euro-americana (CISPEA), a broader and more ambitious consortium comprising Bologna (Bonazzi and Raffaella Baritono), Florence (Romero and Alessandra Lorini), Piemonte Orientale (Vaudagna), and Trieste (Vezzosi and Ellen Migliorino Ginzburg). Addressing "The Atlantic Connection" to "unravel the complexities of political, social, cultural, economic, and international history", in July 2005 the CISPEA held its first summer school, entitled "The U.S. and the European Nations: The Issue of American Exceptionalism." 19

It remains to be seen whether and to what extent U.S. history in Italy will be able to confront its long-standing challenge of combining cultural authority and institutionalization in a changing academic environment. Over the past decade this environment has undergone a complex process of reform, whose impact is difficult to gauge, given its still largely unfinished nature..$^{20}$ Predicated on the autonomy of the individual universities and on a drastic reconfiguration of the structure of degree courses, with a curriculum overhaul beginning in 2001, the reform has yielded a demand for shorter and more basic courses, at least as far as the B.A. degree is concerned, a demand that will probably tend to increase the importance of the more important and more established topics and disciplines such as modern and contemporary history. Increasingly dark financial prospects, especially for the humanities and the historical disciplines ${ }^{21}$, may reinforce this selective tendency, making it harder to carry out research in extra-European area studies. Yet the active presence of Italian Americanists at an international level, as well as their efforts at heeding any sign of "cosmopolitan" curiosity that may arise from the larger historical community in the country ${ }^{22}$, bode well for the survival and growth of U.S. history in Italy.

\section{NOTES}

1. U.S. History is used here in the strictest sense of the term, leaving aside American literary studies, on which see above, Maria Anita Stefanelli, "State of the Art of American Literary Studies in Italy". The relationship of fruitful cooperation and exchange between the two fields goes well beyond the confines of the present article. On this relationship, see the websites of the Associazione Italiana di Studi NordAmericani (AISNA) and of Acoma (edited by Bruno Cartosio, Giorgio Mariani, and 
Alessandro Portelli), the main periodical based on a collaboration between historians and literary scholars.

2. Maurizio Vaudagna, "The American Historian in Continental Europe: An Italian Perspective," Journal of American History, 79 (September 1992), 541. Bibliographical data on the era 1945-1992 can be found in Tiziano Bonazzi, "American History: The View from Italy," and Ferdinando Fasce, "American Labor History, 1973-1983: Italian Perspectives," both in Reviews in American History 14 (December 1986), 523-541 and 601-608, respectively, and, more recently, in Luca Codignola, "From the Witness Stand: A Prosopography of American History in Italy in the Post-war Decades, 1945-1978 ", and Matteo Sanfilippo, "American History in Italy After the Bicentennial Celebrations, 1978-1992: A Discipline in Search of an Identity", forthcoming in Massimo Bacigalupo and Gabriella Ferruggia, eds., Ambassadors: American Studies in a Changing World. Proceedings of the Thirtieth Anniversary $17^{\text {th }}$ Biennial Conference of the Italian Association for North American Studies. Rome 6-8 November 2003 (Turin: OTTO Editore, 2005).

3. Federico Romero, "Dalla convergenza alla divaricazione: l'America nell'immaginario dell'Europa occidentale", in Tiziano Bonazzi, ed., Quale occidente, occidente perché (Soveria Mannelli, Rubbettino, 2005), 189-201; Massimo Teodori, Maledetti americani. Destra, sinistra e cattolici: storia del pregiudizio antiamericano (Milan: Mondatori, 2002). 4. On this approach, see Francois Weil, "Do American Historical Narratives Travel?" in Thomas Bender, ed., Rethinking American History in a Global Age (Berkeley: University of California Press, 2002), 329. Bender's book is the most thorough and insightful discussion on the current state and future prospects of U.S. history from a transnational perspective. See also Michael Kammen, "Clio, Columbia, and the Cosmopolitans: Beyond American Exceptionalism and the Nation-State," History and Theory, 42 (February 2003), 106-115.

5. John Paul Russo, The Future Without the Past. The Humanities in a Technological Society (Columbia: University of Missouri Press, 2005) explores skilfully the fate of the humanities in our times.

6. For these data, see htpp://php3.sp2.cineca.it/murst-dae/pers_docente/ ricerca_docenti/php.3, accessed on 31 January 2005.

7. Anna Maria Martellone, "Italian Historians and the History of the United States: A Difficult Journey", forthcoming in

Massimo Bacigalupo and Gabriella Ferruggia, eds., Ambassadors. To strengthen her argument Martellone also points to the rolls of the Organization of American Historians foreign-language book and article prizes, featuring several Italian scholars among the winners in both categories. 8. Raimondo Luraghi, A History of the Confederate Navy (Annapolis: Naval Institute Press, 1996); Tiziano Bonazzi, "Tradurre/Tradire: The Declaration of Independence in the Italian Context," Journal of American History, 85 (March 1999), 1350-1361; Luca Codignola, "The Holy See and the Conversion of the Indians in French and British North America, 1486-1760," in Karen Ordahl Kupperamn, ed., American European Consciousness, 1493-1750 (Chapel Hill: The University of North Carolina Press for the Institute of Early American History and Culture, 1995), 195-242; Ellen Migliorino Ginzburg, Donne contro la schiavitù. Le abolizioniste americane prima della Guerra Civile, (Manduria: Lacaita, 2002); Susanna Delfino and Michele Gillespie, eds., Neither Lady nor Slave. Working Women of the Old South, (Chapel Hill: University of North Carolina Press, 2002); Marco Sioli, "Breaking into the Trans-Mississippian Frontiers: Thomas Jefferson's Expeditions to the West," in Cornelis A. van Minnen and Sylvia Hilton, eds., Frontiers and Boundaries in U.S. History (Amsterdam: VU University Press, 2004), 69-88. A student of Loretta Valtz Mannucci, 
Sioli is also a member of Valtz Mannucci's influential Milan Group in Early American History, a network that, after two decades, recently relocated to Montpellier renaming itself the Milan-Montpellier Group. It is also worth mentioning Valeria Gennaro Lerda's active role in the formation of the Southern Studies Forum, a pilot international network created at the 1988 EAAS Conference in Berlin, which held its inaugural symposium in Genoa, where Gennaro Lerda has been teaching both U.S. and Canadian history for over thirty years now. See Valeria Gennaro Lerda and Tjebbe Westendorf, eds., The United States South: Regionalism and Identity (Rome: Bulzoni, 1991).

9. Donna R. Gabaccia and Fraser M. Ottanelli, eds., Italian Workers of the World. Labor Migration and the Formation of Multiethnic States (Urbana and Chicago: University of Illinois Press, 2001).

10. The Vatican Archives were first used by Luca Codignola as a vantage point from which to look at Canadian and early North American history. See Tiziano Bonazzi, "American History: The View from Italy," Reviews in American History 14 (December 1986), 532.

11. Matteo Sanfilippo, Problemi di storiografia dell'emigrazione italiana (Viterbo: Sette Città, 2005).

12. Federico Romero, The United States and the European Trade Union Movement, 1944-1951 (Chapel Hill: University of North Carolina Press, 1994); Leopoldo Nuti, Gli Stati Uniti e l'apertura a sinistra, (Roma-Bari, Laterza, 1999); Federica Pinelli- Marco Mariano, Europa e Stati Uniti secondo il New York Times. La corrispondenza estera di Anne O'Hare McCormick 1920-1954 (Turin: OTTO editore, 2000); Daniela Rossini, Il mito americano nell'Italia della Grande Guerra (Roma-Bari: Laterza, 2000); Mario Del Pero, L'alleato scomodo. Gli USA e la DC negli ani del centrismo (1948-1955) (Rome: Carocci, 2001) and "American Pressures and Their Containment in Italy during the Ambassadorship of Clare Boothe Luce, 1953-1956," Diplomatic History 28 (June 2004), 407-439; Antonio Donno, ed., Ombre di guerra fredda. Gli Stati Uniti nel Medio Oriente durante gli anni di Eisenhower (1953-1961) (Naples: Edizioni Scientifiche Italiane, 1998).

13. Michele Nani, "Storia contemporanea ieri e oggi. La produzione della contemporaneistica italiana nello specchio delle riviste $(1987,1994,2001)$, "Novecento, 11 (July-December 2005), 28.

14. See Meg Jacobs-William J. Novak-Julian Zelizer, eds., The Democratic Experiment (Princeton: Princeton University Press, 2003).

15. Oliviero Bergamini, Un esercito per la nazione. Elihu Root e la nascita del moderno sistema militare degli Stati Uniti (Milan: Marcos y Marcos, 1996); Alessandra Lorini, Rituals of Race. American Public Culture and the Search for Racial Democracy (Charlottesville: University Press of Virginia, 1999); Bruno Cartosio, Da New York a Santa Fé. Terra, culture native, artisti e scrittori nel Sudovest (1846-1930) (Florence: Giunti, 1999); Marco Mariano, Lo storico nel labirinto. Arthur M. Schlesinger jr. tra ricerca storica, impegno civile e politica (Milan: Angeli, 1999); Ferdinando Fasce, La democrazia degli affari. Comunicazione aziendale e discorso pubblico negli Stati Uniti, 1900-1940, (Rome: Carocci, 2000); Raffaella Baritono, La democrazia vissuta. Individualismo e pluralismo nel pensiero di Mary Parker Follett (Turin: La Rosa, 2001); Daria Frezza, Il leader, la folla, la democrazia nel discorso pubblico americano 1880-1941 (Rome: Carocci, 2001); Elisabetta Vezzosi, Madri e Stato. Politiche sociali negli Stati Uniti del Novecento (Rome: Carocci, 2001); Daniele Fiorentino, Le tribù devono sparire. La politica di assimilazione degli indiani negli Stati Uniti d'America (Rome: Carocci, 2001); Cristina Scatamacchia, Nellie Bly. Un'avventurosa giornalista e viaggiatrice americana dell'Ottocento (Perugia: Morlacchi, 2002); Arnaldo Testi, Trionfo e declino dei partiti politici 
di massa negli Stati Uniti, 1860-1930, (Turin: OTTO editore, 2000) and Stelle e strisce. Storia di una bandiera (Turin: Bollati Boringhieri, 2004); Antonio Donno, In nome della libertà. Conservatorismo americano e guerra fredda, (Florence: Le Lettere, 2004).

16. Raffaella Baritono, Daria Frezza, Alessandra Lorini, Maurizio Vaudagna, Elisabetta Vezzosi, eds., Public and Private in American History. State, Family, Subjectivity in the Twentieth Century (Turin: OTTO editore, 2003).

17. David K. Adams-Maurizio Vaudagna, eds., Transatlantic Encounters. Public Uses and Misuses of History in Europe and the United States (Amsterdam: VU University Press, 2000); R. Laurence Moore and Maurizio Vaudagna, eds., The American Century in Europe (Ithaca: Cornell University Press, 2003).

18. CSEA publications include Valeria Gennaro Lerda and Roberto Maccarini, eds., Canadian and American Women. Moving from Private to Public Experiences in the Atlantic World (Milan: Selene, 2001) and Valeria Gennaro Lerda, ed., "Which Global Village"? Societies, Cultures, and Political-Economic Systems in a Euro-Atlantic Perspective (Westport: Praeger: 2002).

19. See cispea@spbo.unibo.it.

20. Giliberto Capano, L'università in Italia (Bologna: Il Mulino, 2000); Giunio Luzzatto, 2001: L'odissea dell'università nuova (Milan: RCS, 2001); “Università, una via per evitare il naufragio", Reset (May-June 2004), n. 83, 35-52; Il Mulino 53 (May-June 2004), special issue on the University reform.

21. Massimo Firpo, "Sulla riforma universitaria," Rivista storica italiana 113 (Spring 2001), 242-262.

22. See the session on Italy-U.S. relations organized by Federico Romero at the 2002 Italian Society for the Study of Contemporary History (SISSCO) conference "The World seen from Italy", now in Agostino Giovagnoli and Giorgio Del Zanna, eds., Il mondo visto dall'Italia (Milan: Guerini e Associati, 2005), 419-429.

\section{INDEX}

Keywords: Emigration, international relations, political history, exceptionalism, Wilsonianism 